University of Nebraska - Lincoln

DigitalCommons@University of Nebraska - Lincoln

\title{
Orchard pollination in Capitol Reef National Park, Utah, USA. Honey bees or native bees?
}

\author{
Vincent J. Tepedino \\ USDA ARS \\ Terry L. Griswold \\ USDA ARS, terry.griswold@ars.usda.gov \\ Diane Gail Alston \\ Utah State University, 5305 Old Main Hill, Logan, UT \\ Trent R. Toler \\ Utah State University, 5305 Old Main Hill, Logan, UT \\ Brosi A. Bradley \\ Juniata College
}

Follow this and additional works at: https://digitalcommons.unl.edu/usdaarsfacpub

Part of the Agricultural Science Commons

Tepedino, Vincent J.; Griswold, Terry L.; Alston, Diane Gail; Toler, Trent R.; and Bradley, Brosi A., "Orchard pollination in Capitol Reef National Park, Utah, USA. Honey bees or native bees?" (2007). Publications from USDA-ARS / UNL Faculty. 233.

https://digitalcommons.unl.edu/usdaarsfacpub/233

This Article is brought to you for free and open access by the U.S. Department of Agriculture: Agricultural Research Service, Lincoln, Nebraska at DigitalCommons@University of Nebraska - Lincoln. It has been accepted for inclusion in Publications from USDA-ARS / UNL Faculty by an authorized administrator of DigitalCommons@University of Nebraska - Lincoln. 


\title{
Orchard pollination in Capitol Reef National Park, Utah, USA. Honey bees or native bees?
}

\author{
Vincent J. Tepedino • Diane Gail Alston • Brosi A. \\ Bradley $•$ Trent R. Toler • Terry L. Griswold
}

Received: 7 April 2006 / Accepted: 15 February 2007 / Published online: 21 March 2007 Springer Science+Business Media B.V. 2007

\begin{abstract}
Capitol Reef National Park in central Utah, USA surrounds 22 managed fruit orchards started over a century ago by Mormon pioneers. Honey bees are imported for pollination, although the area in which the Park is embedded has over 700 species of native bees, many of which are potential orchard pollinators. We studied the visitation of native bees to apple, pear, apricot, and sweet cherry over 2 years. Thirty species of bees visited the flowers but, except for pear flowers, most were uncommon compared to honey bees. Evidence that honey bees prevented native bees from foraging on orchard crop flowers was equivocal: generally, honey bee and native bee visitation rates to the flowers were not negatively correlated, nor were native bee visitation rates positively correlated with distance of orchards from honey bee hives. Conversely, competition was tentatively suggested by much larger numbers of honey bees than natives on the flowers of apples, apricots and cherry; and by the large increase of native bees on pears, where honey bee numbers were low. At least one-third of the native bee species visiting the flowers are potential pollinators, including cavity-nesting species such as Osmia lignaria propinqua, currently managed for small orchard pollination in the US, plus several fossorial species, including one rosaceous flower specialist (Andrena milwaukiensis). We suggest
\end{abstract}

\footnotetext{
V. J. Tepedino $(\bowtie) \cdot$ T. L. Griswold

Department of Biology, USDA ARS, Bee Biology \& Systematics Lab., Utah State University, Logan, UT 84322-5310, USA

e-mail: andrena@biology.usu.edu

D. G. Alston · T. R. Toler

Department of Biology, Utah State University, 5305 Old Main Hill, Logan, UT, 84322-5305, USA

B. A. Bradley

Juniata College, 1700 Moore Street, Box 1071, Huntingdon, PA 16652, USA

Present Address:

T. R. Toler

HDR Engineering Inc., 3995 S 700 E, Suite 100, Salt Lake City, UT 84107-2594, USA
} 
that gradual withdrawal of honey bees from the Park would help conserve native bee populations without decreasing orchard crop productivity, and would serve as a demonstration of the commercial value of native pollinators.

Keywords Apoidea $\cdot$ bees $\cdot$ biodiversity $\cdot$ competition $\cdot$ conservation $\cdot$ orchard crops $\cdot$ park $\cdot$ pollination

\section{Introduction}

Among the important services potentially available to agriculture from natural ecosystems is pollination (Parker et al. 1987; Kremen et al. 2002). While most agricultural pollination needs are currently satisfied by importing honey bees during flowering (Free 1993; Delaplane and Mayer 2000), there has long been a call for more effective use of native, solitary bees (Parker et al. 1987). That call is no less warranted today with the urge to sustainable agriculture (Tilman et al. 2002; Rao et al. 2004). Several studies, mostly in the past half decade, have shown how important native pollinators can be to agricultural crop production (Kevan 1977; Kremen et al. 2002; Klein et al. 2003; Ricketts 2004; Morandin and Winston 2005; Blanche et al. 2006; Bosch et al. 2006, Greenleaf and Kremen 2006a, b).

Sustainable use of native pollinators is frequently complicated by absence of nearby nesting habitat (Kremen et al. 2002; Potts et al. 2005), broadscale insecticide applications (Kevan 1977; Kremen et al. 2002), and crop rotations. Once a crop has been changed, particularly from a bee-pollinated to a wind-pollinated species, unless substitutes exist, bee species typically leave the area or die for lack of forage, and are gone when the rotation returns to the bee-pollinated crop. Better suited for sustainable native bee pollination services are orchard crops which typically have a much longer life span and are not treated with insecticides during bloom. Indeed, in the past, in many areas, orchard crops were pollinated mostly by native bees and might be so again (Batra 1995).

An excellent place to examine the contribution of native pollinators to orchard crop production is in Capitol Reef National Park in central Utah, USA. National parks in the United States are typically managed to exclude all exploitative human activity; commonly they allow only such uses as hiking and sight-seeing (National Park Service, web site). Capitol Reef National Park is an exception in that it surrounds the Mormon pioneer settlement of Fruita, a small agricultural community between the Fremont River and Sulphur Creek begun in the latter half of the 19th century (Gilbert and McKoy 1997). Although no longer a "proper" town with residents, Fruita's 22 irrigated orchards continue to be maintained as a historic attraction and a "pick-and-pay" operation by the National Park Service. They are surrounded by an arid, highly dissected, topographically and geologically diverse area rich in plant taxa (Heil et al. 1993 recorded 759 species). Thirty-four plant communities have been described (Romme et al. 1993) including several badland, grassland, woodland and riparian communities.

For at least the past three decades, Park policy has been to pollinate these orchard crops by bringing in commercial honey bee hives. No attempt has been made to catalog the native pollinator fauna visiting these crops or to determine if native species might provide adequate pollination without honey bee supplementation. Use of native pollinators is especially promising because Capitol Reef National Park 
is rich in native bees [Utah has over 1,000 species, and the Colorado Plateau, in which the Park is embedded, has upwards of 700 (Griswold, unpublished)]. Some of these species are likely to visit and pollinate large, open tree fruit flowers that supply both pollen and nectar. Enabling natives to pollinate these crops might satisfy not only the Park's orchard preservation program but its biodiversity preservation objective as well. We therefore undertook an exploratory study with the following objectives: (1) collect and identify the native bees that visit four orchard crops in the Park; (2) estimate the abundance, diversity, and visitation rates of insects visiting orchard crop flowers; (3) evaluate the potential of developing native bees as primary pollinators of orchard crops in the Park; (4) ask whether the Park should rescind or maintain its present policy of honey bee use.

\section{Methods}

Orchards in the Park are variable in size (0.2-3.2 ha) and typically contain several fruit species. A few have understories of alfalfa (Medicago sativa L.) which begins blooming in mid-June. Others have a variety of native and alien plant species in the understory and adjacent to it. To suppress populations of the troublesome codling moth (Cydia pomonella (L.)), apple and pear trees in all orchards typically are thrice sprayed with Phosmet (Imidan ${ }^{\circledR} 70-\mathrm{W}$ at $4.5 \mathrm{~kg}$ per ha; Gowan Company, Yuma, AZ) each season with an orchard air blast sprayer at 3-week intervals beginning about 3 weeks after cessation of bloom.

We surveyed visitors to the flowers of four orchard crops on randomly chosen, permanently tagged, trees in 2003 and 2004. In each year, honey bee hives were placed in the Cook orchard (Fig. 1) from the beginning of apricot bloom in midMarch until the end of apple bloom in early May, whereupon they were withdrawn from the Park.

In 2003, we surveyed self-incompatible "Bartlett" pear (Pyrus communis L.) in the Holt and Chestnut orchards from April 12 to 21 and "Delicious" apple (Malus domestica Borkh) in the Holt and Mott orchards from April 24 to 30. Six trees of each crop within easy walking distance of each other were selected in each orchard. On each tree we counted the number of visits to an easily observable patch (approximate area $61 \mathrm{~cm}^{2}$ ) with between 10 and 20 flowers for $10 \mathrm{~min}$. Blossom patches on each of the six trees were observed in succession for a total of $1 \mathrm{~h}$ in the morning (between 1,000 and 1,200) and afternoon (between 1,500 and 1,700) on 3 days for pear and on 4 days for apple during peak bloom. The same blossom patches were observed in morning and afternoon. Orchards were observed simultaneously by different observers. All flower visitors were recorded to the lowest determinable taxonomic unit (usually genus). To obtain a pollinator reference collection, and estimate relative abundance, specimens of each insect taxon visiting the flowers were collected in each orchard in the hour immediately following each observation period.

In 2004, to increase the accuracy of our estimates of visitation rate, we observed and collected pollinators on known numbers of flowers of self-compatible "Moorpark" and "Sweetpit" apricot (Prunus armeniaca L.) and a mixture of self-incompatible sweet cherry (Prunus avium L.) cultivars. Apricots were surveyed in Max Krueger, Cass Mulford, Adams, Cook, Merin Smith, and Mott orchards from March 15 to 25. Sweet cherry was surveyed in Tine Oyler South, Holt, Abie Clarke, and Cook orchards from March 25 to April 6. Pollinator observation bouts were $30 \mathrm{~min}$ long 


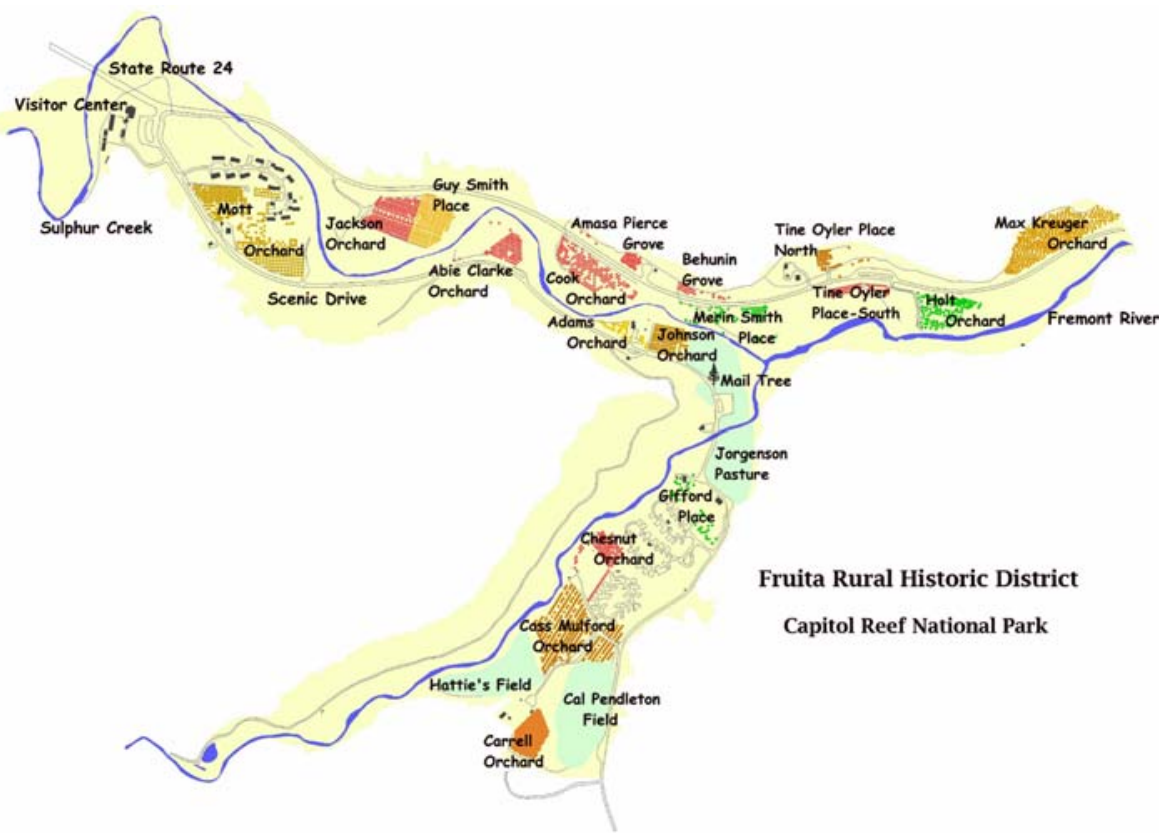

Fig. 1 Map of the Fruita Historic District in Capitol Reef National Park showing the approximate size and position of the orchards

and were repeated in each orchard 4-22 times depending on orchard size (large orchards received more attention than small orchards) during the morning (between 09:45 and 12:00) and afternoon (between 1,400 and 1,700). Pollinators were collected during $30 \mathrm{~min}$ bouts following observation periods. Unlike 2003, in 2004 we sought only to estimate species richness, not relative abundance, and captured only distinct kinds of flower visitors.

Pollinator activity data are presented as visitation rates (mean numbers per flower patch per hr for 2003; mean numbers per flower per $30 \mathrm{~min}$ in 2004). Data from 2004 were used to compare pollinator visitation rates between fruit crops, time of day, and bee type with analysis of variance using a factorial design (Proc Glm, SAS Institute 2003). Linear regression was used to relate pollinator activity in 2004 and (1) ambient temperature (using data from the nearby Park Service weather station) during observation periods in apricot and cherry orchards, and (2) distance from orchards to honey bee hives. The Pearson Correlation Coefficient was used to associate flower visitation rates between honey bees and native bees for 2004 .

\section{Results}

\section{Pollinator diversity}

Collections of insects visiting orchard crop flowers yielded about 30 species of bees, all native but the honey bee (Table 1). Over half (19) of the bee taxa were uncommon, being represented by fewer than five individuals over the four orchard 
Table 1 Number of bees, by species, captured on "Bartlett" pear, "Red Delicious" apple, apricot, and sweet cherry in 10 orchards in Fruita, UT during bloom in 2003 and 2004

\begin{tabular}{|c|c|c|c|c|c|c|c|c|c|c|c|c|c|c|}
\hline \multirow[t]{2}{*}{ Genus } & \multirow[t]{2}{*}{ Species } & \multicolumn{2}{|c|}{ Pear } & \multicolumn{2}{|c|}{ Apple } & \multicolumn{5}{|c|}{ Apricot } & \multicolumn{3}{|c|}{ Cherry } & \multirow[t]{2}{*}{ Total } \\
\hline & & $\mathrm{Ch}$ & $\mathrm{H}$ & $\mathrm{H}$ & Mo & A Co & $\mathrm{K} \mathrm{N}$ & $\mathrm{Me}$ & Mo & $\mathrm{Mu}$ & $\mathrm{Cl} \mathrm{Co}$ & $\mathrm{H}$ & TO & \\
\hline \multirow[t]{11}{*}{ Andrena } & aff. $w$-scripta & & & & & & & 1 & & 1 & 1 & 2 & 2 & 7 \\
\hline & cerasifolii & 12 & 9 & 1 & 3 & & & & & 1 & $*$ & 2 & 1 & 29 \\
\hline & $\begin{array}{l}\text { macoupinensis } \\
\text { milwaukeensis }\end{array}$ & 14 & 12 & 4 & 5 & & & & & 1 & $* *$ & $\begin{array}{l}1 \\
2\end{array}$ & 2 & $\begin{array}{r}1 \\
40\end{array}$ \\
\hline & $\begin{array}{l}\text { prunorum } \\
\text { prunorum }\end{array}$ & 23 & 32 & 6 & 18 & 3 & 11 & & 1 & 5 & 41 & 8 & 2 & 105 \\
\hline & (Euandrena) sp. 1 & & & & & 1 & & & & 1 & 2 & & & 4 \\
\hline & sp. 2 & & & & & & & & & & & 1 & & 1 \\
\hline & sp. $C R 4$ & & 1 & & & & & & & & & & & 1 \\
\hline & striatifrons & & & & & & & & & & & 1 & 1 & 2 \\
\hline & $w$-scripta & 14 & 10 & 2 & 5 & & & 2 & & 1 & 81 & 4 & 3 & 50 \\
\hline & zionensis & 4 & 2 & & 1 & & & & & & & & & 7 \\
\hline & spp. & & & & & & & & * & & & & & * \\
\hline \multirow{3}{*}{ Anthophora } & edwardsi & & & & & & & & & & & 1 & & 1 \\
\hline & neglecta & & & & & & 1 & & & & 1 & & 1 & 3 \\
\hline & porterae & & & & & $1 *$ & $2 *$ & & * & 1 & 31 & 3 & 2 & 13 \\
\hline Apis & mellifera & 7 & 8 & 5 & 12 & $1 *$ & 6 & & & $*$ & $* *$ & $*$ & * & 39 \\
\hline \multirow[t]{2}{*}{ Bombus } & huntii & & & & 1 & & & & & & & & & 1 \\
\hline & $s p$ & & & & & * & * & & & & & & & * \\
\hline Halictus & tripartitus & & & 1 & & & & & & & & & & 1 \\
\hline \multirow[t]{5}{*}{ Lasioglossum } & $\begin{array}{l}\text { (Dialictus) } s p . \\
\text { egregium }\end{array}$ & 1 & 1 & & 3 & & & & & & 11 & & 3 & $\begin{array}{l}7 \\
3\end{array}$ \\
\hline & $\begin{array}{l}\text { pulveris } \\
\text { sisymbrii }\end{array}$ & 36 & 14 & 14 & $\begin{array}{r}22 \\
1\end{array}$ & 11 & 32 & & & & 131 & 9 & 2 & $\begin{array}{r}118 \\
1\end{array}$ \\
\hline & sp. E2 & 13 & & 1 & 1 & & 12 & & & 13 & & 2 & 2 & 44 \\
\hline & tegulariforme & & & 2 & & & & & & & & & & 2 \\
\hline & sp. $C R 1$ & & & 1 & & & & & & & & & & 1 \\
\hline Nomada & sp. CR2 & & & 1 & & & & & & & & & & 1 \\
\hline \multirow[t]{3}{*}{ Osmia } & $\begin{array}{l}\text { lignaria } \\
\text { propinqua }\end{array}$ & 13 & 8 & 11 & 1 & 51 & 73 & & 1 & 9 & 113 & 13 & 6 & 92 \\
\hline & ribifloris ribifloris & & 1 & 2 & & & 9 & & & 2 & 1 & 1 & & 16 \\
\hline & & & & 1 & & & & & & & & & & 1 \\
\hline \multirow[t]{2}{*}{ Xylocopa } & $\begin{array}{l}\text { californica } \\
\text { arizonensis }\end{array}$ & & & 1 & 1 & & & & & & & & & 2 \\
\hline & $\begin{array}{c}\text { tabaniformis } \\
\text { androleuca }\end{array}$ & & & & 1 & & & & & & & & & 1 \\
\hline Total & & 137 & 98 & 53 & 75 & 122 & 419 & 9 & 2 & 35 & 449 & 50 & 27 & 594 \\
\hline
\end{tabular}

Orchard names: A, Adams; Ch, Chestnut; Cl, Clarke; Co, Cook; H, Holt; K, Krueger; Me, Merin Smith Place; Mo, Mott; Mu, Mulford; TO, Tine Oyler *, observed, but not collected

crop-years. Fewer total bees were collected in 2004 (231) than in 2003 (363) despite more than twice as many hours spent collecting in 2004 . This difference was due to our effort, in 2003, to obtain a representation of both species occurrence and relative abundance, whereas, in 2004, we sought only to estimate species richness.

Bee species richness and numbers visiting the flowers varied by crop (Table 1). Almost twice as many native bee individuals were captured on pear than on apple in 2003. Slightly more native bees were collected on cherry than apricot in 2004. Twenty species were captured in apple, 18 species in cherry, 15 in apricot, and 12 in pear. Ten species visited both pear and apple, 13 species were shared by apricot and 
Table 2 Mean (SE) visits per flower patch per hour at Capitol Reef National Park, 2003 by crop (pears, apples), time (T; AM, PM), and insect taxa (Apis, Native bees-NAT, flies-FL, totalsTOT)

\begin{tabular}{|c|c|c|c|c|c|c|c|c|c|c|c|}
\hline \multirow[t]{2}{*}{ Orchard } & \multirow[t]{2}{*}{ Dates } & \multirow[t]{2}{*}{$N$} & \multirow[t]{2}{*}{ Time } & \multicolumn{8}{|c|}{ Visitation rate } \\
\hline & & & & TOT & SE & Apis & SE & NAT & SE & FL & SE \\
\hline \multicolumn{12}{|l|}{ Pears } \\
\hline Holt & $4 / 12-21$ & $\begin{array}{l}3 \\
3\end{array}$ & $\begin{array}{l}\mathrm{AM} \\
\mathrm{PM}\end{array}$ & $\begin{array}{l}9.7 \\
9.7\end{array}$ & $\begin{array}{l}5.7 \\
5.0\end{array}$ & $\begin{array}{l}6.7 \\
2.7\end{array}$ & $\begin{array}{l}4.3 \\
1.2\end{array}$ & $\begin{array}{l}1.7 \\
4.3\end{array}$ & $\begin{array}{l}1.2 \\
2.2\end{array}$ & $\begin{array}{l}1.3 \\
2.7\end{array}$ & $\begin{array}{l}0.7 \\
2.2\end{array}$ \\
\hline Chestnut & $4 / 12-21$ & $\begin{array}{l}3 \\
3\end{array}$ & $\begin{array}{l}\mathrm{AM} \\
\mathrm{PM}\end{array}$ & $\begin{array}{l}22.0 \\
10.3\end{array}$ & $\begin{array}{l}8.4 \\
2.3\end{array}$ & $\begin{array}{l}7.0 \\
2.0\end{array}$ & $\begin{array}{l}3.6 \\
1.2\end{array}$ & $\begin{array}{r}12.7 \\
6.7\end{array}$ & $\begin{array}{l}5.9 \\
2.6\end{array}$ & $\begin{array}{l}2.3 \\
1.7\end{array}$ & $\begin{array}{l}0.7 \\
0.9\end{array}$ \\
\hline Totals & & $\begin{array}{l}6 \\
6\end{array}$ & $\begin{array}{l}\mathrm{AM} \\
\mathrm{PM}\end{array}$ & $\begin{array}{l}15.8 \\
10.0\end{array}$ & $\begin{array}{l}5.3 \\
2.5\end{array}$ & $\begin{array}{l}6.8 \\
2.3\end{array}$ & $\begin{array}{l}2.5 \\
0.8\end{array}$ & $\begin{array}{l}7.2 \\
5.5\end{array}$ & $\begin{array}{l}3.7 \\
1.6\end{array}$ & $\begin{array}{l}1.8 \\
2.2\end{array}$ & $\begin{array}{l}0.5 \\
1.1\end{array}$ \\
\hline Pear total & & & & 12.9 & 2.9 & 4.6 & 1.4 & 6.3 & 1.9 & 2.0 & 0.6 \\
\hline $\begin{array}{l}\text { Apples } \\
\text { Holt }\end{array}$ & 4/24-30 & $\begin{array}{l}4 \\
4\end{array}$ & $\begin{array}{l}\text { AM } \\
\text { PM }\end{array}$ & $\begin{array}{l}36.0 \\
37.5\end{array}$ & $\begin{array}{l}13.3 \\
15.4\end{array}$ & $\begin{array}{l}30.8 \\
29.0\end{array}$ & $\begin{array}{l}12.5 \\
13.6\end{array}$ & $\begin{array}{l}2.0 \\
3.3\end{array}$ & $\begin{array}{l}0.4 \\
0.5\end{array}$ & $\begin{array}{l}3.3 \\
5.3\end{array}$ & $\begin{array}{l}1.4 \\
1.7\end{array}$ \\
\hline Mott & $4 / 24-30$ & $\begin{array}{l}4 \\
4\end{array}$ & $\begin{array}{l}\mathrm{AM} \\
\mathrm{PM}\end{array}$ & $\begin{array}{l}49.0 \\
63.0\end{array}$ & $\begin{array}{l}10.8 \\
21.6\end{array}$ & $\begin{array}{l}44.0 \\
46.8\end{array}$ & $\begin{array}{l}11.8 \\
16.7\end{array}$ & $\begin{array}{l}1.3 \\
3.0\end{array}$ & $\begin{array}{l}1.3 \\
1.6\end{array}$ & $\begin{array}{r}3.8 \\
13.3\end{array}$ & $\begin{array}{l}1.8 \\
5.5\end{array}$ \\
\hline Totals & & $\begin{array}{l}8 \\
8\end{array}$ & $\begin{array}{l}\text { AM } \\
\text { PM }\end{array}$ & $\begin{array}{l}42.5 \\
50.3\end{array}$ & $\begin{array}{r}8.3 \\
13.2\end{array}$ & $\begin{array}{l}37.4 \\
37.9\end{array}$ & $\begin{array}{r}8.3 \\
10.5\end{array}$ & $\begin{array}{l}1.6 \\
3.1\end{array}$ & $\begin{array}{l}0.6 \\
0.8\end{array}$ & $\begin{array}{l}3.5 \\
9.3\end{array}$ & $\begin{array}{l}1.1 \\
3.1\end{array}$ \\
\hline Apple total & & 16 & & 46.4 & 7.6 & 37.6 & 6.5 & 2.4 & 0.5 & 6.4 & 1.7 \\
\hline
\end{tabular}

$N=$ number of 60-min observation periods; Dates are dates of observations. See Table 3 for distances from hives to orchards (distance from hives to Chestnut $=650 \mathrm{~m}$ )

cherry, and nine species visited all four fruit crops. The most common native bee species were spring-flying, ground-nesting Andrena prunorum prunorum and Lasioglossum pulveris, and the cavity-nesting Osmia lignaria propinqua. Only O. l. propinqua, was present on all four crops in all orchards studied. Other frequently collected native bees included three additional species of Andrena, Anthophora porterae (from apricot and cherry only), a species of Lasioglossum, and $O$. ribifloris ribifloris. All nest in the ground except the cavity-nesting $O$. r. ribifloris.

Dipterans were common flower visitors only in 2003 when 23 species of flies, most incidental, were collected in pear and apple orchards. Syrphids (hover flies) were especially abundant in 2003 (Table 2; seven species) but were uncommon in 2004 (see below).

\section{Pollinator visitation}

We found large differences between tree crops in overall flower patch visitation rates in 2003 (Table 2): apples were visited significantly more frequently than pears (apple 46.4, pear 12.9 insect visits per flower patch per hour; $t$-test (unequal variances $)=4.1, P=0.0006)$. The low rate of visitation to pears was due primarily to fewer honey bee visits (honey bees averaged 37.6 visits per hour to apples but only 4.6 visits per hour to pears). Flies were also more abundant on apples. In contrast, native bees were more abundant on pears (6.3 visits per hour) than on apples $(2.4$ visits per hour).

In 2004 we counted the actual number of flowers observed for apricots and cherries. Total bee visits per flower per hour was almost five times greater in apricots 黛 Springer 
Table 3 Mean (SE) visits per flower per 30 min at Capitol Reef National Park, 2004 by crop (apricot, sweet cherry), time (AM, PM) and bee taxa (Apis, natives, totals)

\begin{tabular}{|c|c|c|c|c|c|c|c|c|c|c|}
\hline \multirow[t]{2}{*}{ Orchard } & \multirow[t]{2}{*}{ Dates } & \multirow[t]{2}{*}{ Dist } & \multirow[t]{2}{*}{ Time } & \multirow[t]{2}{*}{$N$} & \multicolumn{6}{|c|}{ Visitation rate } \\
\hline & & & & & TOT & SE & Apis & SE & NAT & SE \\
\hline \multicolumn{11}{|l|}{ Apricot } \\
\hline \multirow{2}{*}{ Adams } & $3 / 21-22$ & 175 & $\mathrm{AM}$ & 4 & 0.66 & 0.24 & 0.60 & 0.24 & 0.05 & 0.04 \\
\hline & & & PM & 6 & 0.14 & 0.06 & 0.12 & 0.05 & 0.01 & 0.01 \\
\hline \multirow[t]{2}{*}{ Cook } & $3 / 23$ & 10 & AM & 3 & 0.11 & 0.04 & 0.10 & 0.03 & 0.0 & 0.0 \\
\hline & & & PM & 2 & 0.11 & 0.09 & 0.08 & 0.08 & 0.03 & 0.01 \\
\hline \multirow[t]{2}{*}{ Krueger } & 3/15-19 & 1,175 & $\mathrm{AM}$ & 10 & 3.57 & 0.72 & 3.48 & 0.71 & 0.04 & 0.02 \\
\hline & & & PM & 12 & 4.63 & 0.90 & 4.11 & 1.01 & 0.37 & 0.21 \\
\hline \multirow[t]{2}{*}{ M. Smith } & $3 / 23-25$ & 400 & AM & 2 & 0.31 & 0.01 & 0.22 & 0.06 & 0.09 & 0.06 \\
\hline & & & PM & 2 & 0.10 & 0.03 & 0.09 & 0.03 & 0.01 & 0.01 \\
\hline \multirow[t]{2}{*}{ Mott } & $3 / 23$ & 700 & $\mathrm{AM}$ & 3 & 0.06 & 0.03 & 0.05 & 0.02 & 0.01 & 0.01 \\
\hline & & & PM & 1 & 0.05 & - & 0.05 & - & 0 & - \\
\hline \multirow[t]{2}{*}{ Mulford } & $3 / 20-24$ & 825 & $\mathrm{AM}$ & 10 & 0.48 & 0.31 & 0.41 & 0.26 & 0.07 & 0.05 \\
\hline & & & PM & 11 & 0.14 & 0.04 & 0.13 & 0.03 & 0.01 & 0.01 \\
\hline \multirow[t]{2}{*}{ Totals } & & & AM & 32 & 1.34 & 0.36 & 1.29 & 0.35 & 0.04 & 0.02 \\
\hline & & & PM & 34 & 1.66 & 0.49 & 1.52 & 0.48 & 0.14 & 0.08 \\
\hline Apricot total & & & & 66 & 1.54 & 0.30 & 1.41 & 0.30 & 0.09 & 0.04 \\
\hline \multicolumn{11}{|l|}{ Cherry } \\
\hline \multirow[t]{2}{*}{ Clarke } & $3 / 26-31$ & 225 & $\mathrm{AM}$ & 12 & 0.39 & 0.08 & 0.35 & 0.09 & 0.02 & 0.01 \\
\hline & & & PM & 11 & 0.21 & 0.03 & 0.15 & 0.04 & 0.04 & 0.01 \\
\hline \multirow[t]{2}{*}{ Cook } & $3 / 28-4 / 6$ & 10 & $\mathrm{AM}$ & 5 & 0.29 & 0.12 & 0.28 & 0.11 & 0.0 & - \\
\hline & & & PM & 3 & 0.15 & 0.08 & 0.14 & 0.08 & 0.0 & 0.0 \\
\hline \multirow[t]{2}{*}{ Holt } & $3 / 26-4 / 6$ & 875 & $\mathrm{AM}$ & 17 & 0.26 & 0.04 & 0.23 & 0.04 & 0.04 & 0.01 \\
\hline & & & PM & 12 & 0.55 & 0.12 & 0.43 & 0.09 & 0.10 & 0.06 \\
\hline \multirow[t]{2}{*}{ T. Oyler } & $3 / 25-4 / 1$ & 650 & $\mathrm{AM}$ & 5 & 0.25 & 0.12 & 0.22 & 0.12 & 0.03 & 0.01 \\
\hline & & & PM & 11 & 0.28 & 0.07 & 0.19 & 0.05 & 0.08 & 0.03 \\
\hline \multirow[t]{2}{*}{ Totals } & & & $\mathrm{AM}$ & 39 & 0.29 & 0.04 & 0.27 & 0.04 & 0.02 & 0.01 \\
\hline & & & PM & 37 & 0.33 & 0.05 & 0.26 & 0.04 & 0.07 & 0.02 \\
\hline Cherry total & & & & 76 & 0.32 & 0.03 & 0.26 & 0.03 & 0.05 & 0.01 \\
\hline
\end{tabular}

$N=$ number of 30-min observation periods; dates are dates of observations; Dist is minimum distance (m) to honey bee hives

than in cherries, and the number of visits by honey bees greatly exceeded visits by native bees on both crops (Table 3 ). Both these effects were highly significant $\left(P<0.0001\right.$; bees $F_{1,276}=26.5$; crops $\left.F_{1,276}=17.6\right)$. There was no effect of time of day $(P>0.50)$ on visits per flower per hour. We also found a significant interaction between fruit crop and bee $\left(F_{1,276}=15.0, P<0.0001\right)$ : honey bees, but not natives, were much less abundant on cherries than on apricots. Unlike the situation for pears in 2003, reduced honey bee numbers were not compensated for by an increase in native bees.

Grouping visitation rates by orchard revealed large inter-orchard differences and one anomaly: apricot bloom in the Krueger orchard attracted many more honey bees than did any other apricot, cherry or pear orchard (Tables 2, 3) despite the fact that Krueger is farther from the honey bee hives than any other orchard examined (see below). Unexpectedly, Krueger also attracted larger numbers of native bees in the afternoon than at any other time or in any other orchard.

The wide variation in visitation rates to flowers was not correlated with temperature as recorded at the Park's weather station near the visitor center (Fig. 1). There 
was no relation between mean temperature during foraging and total insect visits to flowers for either apricot $\left(F_{1,64}=0.36, P>0.50\right)$ or sweet cherry $\left(F_{1,74}=0.15\right.$, $P>0.50)$ observation periods. When honey bees and native bees were examined separately for each crop, the only significant result of the four comparisons was for native bees and sweet cherry $\left(F_{1,74}=6.45, P=0.013\right)$ but even here $R^{2}$ was only 0.08 suggesting a minor effect at best. No other comparison was significant (all $P>0.10$ ).

We hypothesized that the negative impacts of honey bees on native bees were inversely related to the distance of orchards from honey bee hives. We tested this in 2004 by comparing the distances from honey bee hives to (1) apricot and (2) sweet cherry orchards with (a) native bee and (b) honey bee activity (visits/flower/hour) separately for morning and afternoon observation sessions. We thus made eight comparisons. Our hypothesis was not supported for any comparison: neither honey bee nor native bee activity in orchards was significantly related to distance to honey bee hives (Table 3; all $P>0.10$ ). In addition, we performed Pearson correlations relating honey bee and native bee activity for each crop for morning and afternoon observations: none of the four comparisons approached significance (all $P>0.25$ ).

Flies (Diptera), especially syrphids (hover flies), were very abundant in the spring of 2003, both in the orchards (Table 2) and on native plants surrounding the orchards (unpublished observations); they were scarce in these areas in 2004. Syrphids were responsible for the majority of visits by Diptera to pear and apple blooms (11-21\% of insect visitors) (Table 2) in 2003. In contrast, Diptera were uncommon visitors to apricot and cherry blooms in 2004 (1-2\% of insect visitors), with the exception of two mornings between March 15 and 17 in apricot. The importance of syrphid visits for orchard crop pollination is not known. Syrphids are generally thought to be relatively poor pollinators because: (1) they are less hairy than bees and carry less pollen on their bodies; (2) they are less likely to make consecutive visits to flowers of the same species; and (3) they visit fewer flowers per unit time because they forage only for their own needs whereas female bees forage for both themselves and their progeny. Syrphids are also unlikely to be reliable pollinators because their densities can vary greatly from year-to-year as in this study.

\section{Discussion}

The flowers of the four rosaceous tree fruit crops we surveyed all supply both pollen and nectar, and are fairly large, open and easily manipulated by insects. Thus, the high richness of insect flower visitors is not surprising: we recorded over 30 native bee species in four families; it is probable that many other species in this bee rich area visited the flowers but were unrepresented in our collections. The species we collected differed greatly in size, morphology, pollen preference, and nesting habit. Among those collected were representatives of both long-tongued (Apidae, Megachilidae) and short-tongued (Andrenidae, Halictidae) families, pollen generalists and relative specialists, and xylophilous and fossorial nesters. We believe that many of these native bee species have great potential to pollinate the Park's orchard crops, i.e., to be more than mere incidental visitors, if their numbers can be increased.

Our reasons for advocating natives as tree crop pollinators in the Park are both specific and general. First, three species are particularly promising pollinators. Osmia lignaria propinqua, the blue orchard bee, is presently used as a commercial pollinator of tree fruit crops in small orchards across the US (Bosch and Kemp 
2001), and is already fairly common in all Capitol Reef orchards. Bosch et al. (2006) have demonstrated a 2- to 5-fold increase in sweet cherry fruit set by using $O$. l. propinqua compared to the honey bee. Another fairly abundant species of potential importance, the ground-nesting Andrena milwaukiensis, prefers flowers in the Rosaceae (LaBerge 1980) and can be relied upon to visit these orchard crops. Many females of the ubiquitous generalist Andrena prunorum might prove to be flower constant foragers of fruit crops if given the opportunity. Other species about which little is presently known could also contribute to the pollination of these tree fruit crops. It is even possible that the low fruit sets currently recorded in the Park (unpublished) for cherry (3-8\%), apricot (6-9\%), apple and pears when honey bees are the primary pollinators might improve and Park revenue increase by encouraging native bees as pollinators.

Second, a major general advantage of employing native species as pollinators of orchard crops in Capitol Reef National Park is reliability, a product of bee species richness. Individual bee species can exhibit large fluctuations in abundance from year-to-year (Cane and Payne 1993; Williams et al. 2001) but these individual fluctuations are not necessarily correlated; frequently they are compensatory. For example, Kremen et al. (2002) showed that the native bee species that were important pollinators of watermelon on organic farms in California varied from year-to-year, and that bee diversity was instrumental in insuring adequate pollination. At least two processes were at work (Kremen 2005): the portfolio effect (the advantage of high species richness when variation of species' abundances is due to random effects), and density compensation (inverse correlations in population numbers between some species). The diverse suite of species visiting orchard crops in the Park (see above) supports the stabilization of pollination services. Reliability of pollinators is especially desirable if honey bee colony numbers continue to decline nationwide compared with the demand for their pollination services. If this continues, colonies will become more expensive to rent and perhaps even unavailable to Park managers because of competition with other, more lucrative crops. If honey bee hives were suddenly unavailable to the Park, the "pick and pay" operation might have to be abandoned, at least temporarily, until native bee populations increased. Better to phase them out now, before a crisis arises.

If many native bees in the Park are well-matched to orchard tree crops, why are they not more numerous on the flowers? Might competition with honey bees be a contributing factor? Though long suspected, competition for pollen and nectar between alien honey bees and native bees has been difficult to demonstrate (Sugden et al. 1996; Butz Huryn 1997; Minckley et al. 2003; Paini 2004; Forup and Memmott 2005; Paini et al. 2005, this study). Competitive exclusion of native bees by honey bees should be more likely in orchards than for many plant populations because honey bees can usurp high density resources by recruiting foragers but native bees cannot (Schaffer et al. 1983). Nevertheless, our results provided inconsistent evidence that imported honey bees kept native bees from foraging on orchard crops in Capitol Reef National Park. Although honey bees were always more abundant than natives on apricot, apple, and cherry blossoms (Tables 2, 3), there was no indication that natives were being excluded from the flowers. In contrast, on pear blossoms, which are ill-favored by honey bees because they produce nectar of low sugar concentration (Free 1993, pp. 451ff.), native bees were more common visitors than honey bees. Whether this was due to competitive release or to other causes is not possible to say. In addition, in concurrent studies of the reproductive biology of 
five rare plant species with populations within $1.4 \mathrm{~km}$ of the orchards, honey bees were absent from, and native bees relatively abundant on, the flowers except for one sampling date at the end of the orchard bloom season (Tepedino and Alston, unpublished). Again, such evidence of competition is less than convincing.

Several other findings were inconsistent with a hypothesis of competitive exclusion. First, we observed no inverse correlation between honey bee and native bee visitation rates. Second, native bee visitation rates did not increase with distance of orchards from honey bee hives. Third, unlike pears, a low visitation rate by honey bees to cherry flowers was not accompanied by an elevated rate of native bee foraging. And finally, the single highest visitation rate by native bees coincided with the highest visitation rate by honey bees, on apricot flowers during afternoons in the Krueger orchard (Table 3). The high Krueger visitation rates may have been due to a warmer microclimate in that orchard which is mostly surrounded on three sides by a red sandstone escarpment.

With this equivocal evidence, is our concern that honey bees pose a threat to native bees in Capitol Reef National Park ill-founded? Indeed, one might argue that honey bees, because of their proclivity to visit plants at high density, may restrict the Park's native bees to native plants. Thus, honey bees may be performing a direct pollination service for orchard crops and an indirect service for native plants so long as they continue to be removed when orchard bloom ceases.

At this point, it is pertinent to recall that a primary Park objective is to preserve native biodiversity and, secondarily, to support orchard productivity. We suggest that both objectives would be better met by gradually removing honey bees and encouraging native bees to replace them as pollinators in the orchards. Continued honey bee presence in the Park, even when limited to orchards at bloom time, runs counter to Park objectives in at least two ways: first, adult bees ingest nectar and some pollen and use those floral resources to rear their progeny. Floral resources consumed by honey bees, whether from native plants or from alien orchard crops that have supplanted natives, translates directly into fewer native bees, whether those resources are strictly limiting or not, and smaller native bee populations are at greater risk of localized extinction. [For example, honey bees, by merely forcing a foraging native bee female to forage longer to gather an equivalent load of resources, expose that female's immature offspring to greater levels of attack because she spends less time in her nest to repel enemies (Goodell 2003)]. Second, despite precautions taken by beekeepers, honey bees may spread into the park and become established (thus far, they appear not to be permanent Park residents), possibly displacing native bees from some native plants with detrimental results for both (Buchmann and Shipman 1996).

Finally, there is the opportunity for the Park to serve as a sustainable and costfree showcase for ecosystem pollination services and to display the unheralded value of native bees. In our efforts to conserve biodiversity we need more such demonstrations of the value of native species.

We advocate a gradual phase-out of honey bees, perhaps over a 5-year period, to begin as soon as possible to allow native bees to fill the orchard pollinator niche. The reduction in honey bee hives should be accompanied by studies of bee visitation rates to, and fruit production of, both orchard flowers and contemporaneous blooming native plants. If native bees are slow to fill the vacuum created by honey bee withdrawal, then the phase-out could be slowed or reversed. Conversely, if after the transition period native pollinators have increased without decline in fruit set of 
orchard crops or native plants, then the hives of honey bee should be completely eliminated.

Acknowledgements We received financial and logistic support from the National Park Service. Their Capitol Reef representatives, Tom and Debbie Clark, and Jeff Pace, were most supportive hosts. Tom Clark, in particular, helped at every stage of this research, including its conception. Jim Cane and a hardworking anonymous reviewer made many constructive comments. Mike Dlugos contributed to data collection in the first year of this study.

\section{References}

Batra SWT (1995) Bees and pollination in our changing environment. Apidologie 26:361-370

Blanche KR, Ludwig JA, Cunningham SA (2006) Proximity to rainforest enhances pollination and fruit set in orchards. J Appl Ecol 43:1182-1187

Bosch J, Kemp WP (2001) How to manage the blue orchard bee. USDA-SARE, Sustainable agriculture network, Handbook series, Book 5, Washington, DC

Bosch J, Kemp WP, Trostle G (2006) Bee population returns and cherry yields in an orchard pollinated with Osmia lignaria (Hymenoptera: Megachilidae). J Econ Entomol 99:408-413

Buchmann SL, Shipman CW (1996) Pollen harvest by Sonoran Desert honey bees: conservation implications for native bees and flowering plants. Desert Plants 12:3-11

Butz Huryn VM (1997) Ecological impacts of introduced honey bees. Q Rev Biol 72:275-297

Cane JH, Payne JA (1993) Regional, annual, and seasonal variation in pollinator guilds: intrinsic traits of bees (Hymenoptera: Apoidea) underlie their patterns of abundance at Vaccinium ashei (Ericaceae). Ann Entomol Soc Am 86:577-588

Delaplane KS, Mayer DF (2000) Crop pollination by bees. CABI Publishing, New York

Forup ML, Memmott J (2005) The relationship between the abundances of bumblebees and honeybees in a native habitat. Ecol Entomol 30:47-57

Free JB (1993) Insect pollination of crops, 2nd edn. Academic Press, New York

Gilbert CA, McKoy KL (1997) Cultural landscape report: Fruita Rural Historic District, Capitol Reef National Park. Cultural Resources Selections, National Park Service, Intermountain Region, No. 8 (also available at http://www.nps.gov/care/resources/CLR/clr.htm)

Goodell K (2003) Food availability affects Osmia pumila (Hymenoptera: Megachilidae) foraging, reproduction, and brood parasitism. Oecologia 134:518-527

Greenleaf SS, Kremen C (2006a) Wild bee species increase tomato production and respond differently to surrounding land use in northern California. Biol Conserv 133:81-87

Greenleaf SS, Kremen C (2006b) Wild bees enhance honey bees' pollination of hybrid sunflower. Proc Natl Acad Sci USA 103:13890-13895

Heil KD, Porter JM, Fleming R, Romme WH (1993) Vascular flora and vegetation of Capitol Reef National Park, Utah. Technical report NPS/NAUCARE/NRTR-93/01. Cooperative Park Studies Unit, Denver CO

Kevan PG (1977) Blueberry crops in Nova Scotia and New Brunswick - Pesticides and crop reductions. Can J Agric Econ 25:61-64

Klein A, Steffan-Dewenter I, Tscharntke T (2003) Fruit set of highland coffee depends on the diversity of pollinating bees. Proc Roy Soc London B 270:855-961

Kremen C (2005) Managing ecosystem services: what do we need to know about their ecology? Ecol Lett 8:468-479

Kremen C, Williams NM, Thorp RW (2002) Crop pollination from native bees at risk from agricultural intensification. Proc Natl Acad Sci USA 99:16812-16816

LaBerge WE (1980) A revision of the bees of the genus Andrena of the western hemisphere. Part X. Subgenus Andrena. Trans Am Entomol Soc 106:395-525

Minckley RL, Cane JH, Kervin L, Yanega D (2003) Biological impediments to measures of competition among introduced honey bees and desert bees. J Kansas Entomol Soc 76:306-319

Morandin LA, Winston ML (2005) Wild bee abundance and seed production in conventional, organic, and genetically modified canola. Ecol Appl 15:871-881

National Park Service. The National Park Service Organic Act. http://www.nps.gov/legacy/organicact.htm

Paini DR (2004) Impact of the introduced honey bee (Apis mellifera) (Hymenoptera: Apidae) on native bees: a review. Austral Ecol 29:399-407 
Paini DR, Williams MR, Roberts JD (2005) No short-term impact of honey-bees on the reproductive success of an Australian native bee. Apidologie 36:613-621

Parker FD, Batra SWT, Tepedino VJ (1987) New pollinators for our crops. Agric Zool Rev 2:279-304

Potts SG, Vulliamy B, Roberts S, O'Toole C, Dafni A, Ne'eman G, Willmer P (2005) Role of nesting resources in organising diverse bee communities in a Mediterranean landscape. Ecol Entomol 30:78-85

Rao NH, Katyal JC, Reddy MN (2004) Embedding the sustainability perspective into agricultural research: implications for research management. Outlook Agric 33:167-176

Ricketts TH (2004) Do tropical forest fragments enhance pollinator activity in nearby coffee crops? Conserv Biol 18:1-10

Romme WH, Heil KD, Porter JM, Fleming R (1993) Plant communities of Capitol Reef National Park, Utah. Technical report NPS/NAUCARE/NRTR-93/02. Cooperative Park Studies Unit, Denver CO

SAS Institute (2003) Version 9.1.3. SAS Institute Inc., Cary, North Carolina

Schaffer WM, Zeh DW, Buchmann SL, Kleinhans S, Schaffer MV, Antrim J (1983) Competition for nectar between introduced honey bees and native North-American bees and ants. Ecology 64:564-577

Sugden EA, Thorp RW, Buchmann SL (1996) Honey bee-native bee competition: focal point for environmental change and apicultural response in Australia. Bee World 77:26-44

Tilman D, Cassman KG, Matson PA, Naylor R, Polasky S (2002) Agricultural sustainability and intensive production practices. Nature 418:671-677

Williams NM, Minckley RL, Silveira FA (2001) Variation in native bee faunas and its implications for detecting community changes. Conserv Ecol 5(1):7. [online] URL http://www.consecol.org/ vol5/iss1/art7/ 